\title{
High rate nitrogen removal by ANAMMOX internal circulation reactor (IC) for
}

\section{old landfill leachate treatment}

The Nhat Phan ${ }^{1}$, Thi Thanh Van Truong ${ }^{1}$, Nhu Biec Ha ${ }^{1}$, Phuoc Dan Nguyen ${ }^{1}$, Xuan Thanh Bui ${ }^{1}$, Bao Trong Dang $^{2,1}$, Van Tuan Doan ${ }^{3}$ Joonhong Park ${ }^{3}$, Wenshan Guo ${ }^{4} \&$ Huu Hao Ngo,*

${ }^{l}$ Faculty of Environment and Natural Resources, University of Technology, Vietnam National University-Ho Chi Minh, Vietnam. Email: bxthanh@hcmut.edu.vn.

${ }^{2}$ Institute of Research and Development, Duy Tan University, Da Nang, Vietnam.

${ }^{3}$ Department of Civil and Environmental Engineering, Yonsei University, Seoul, Korea.

${ }^{4}$ Centre for Technology in Water and Wastewater, School of Civil and Environmental Engineering, University of Technology Sydney, Broadway, NSW 2007, Australia.Email:h.ngo@uts.edu.au.

\section{Abstract}

This study aimed to evaluate the performance of a high rate nitrogen removal lab-scale ANAMMOX reactor, namely Internal Circulation (IC) reactor, for old landfill leachate treatment. The reactor was operated with pre-treated leachate from a pilot Partial Nitritation Reactor (PNR) using a high nitrogen loading rate ranging from 2 to $10 \mathrm{~kg} \mathrm{~N} \mathrm{~m}^{-3} \mathrm{~d}^{-1}$. High rate removal of nitrogen $\left(9.52 \pm 1.11 \mathrm{~kg} \mathrm{~N} \mathrm{~m}^{-3} \mathrm{~d}^{-1}\right)$ was observed at an influent nitrogen concentration of $1,500 \mathrm{mg} \mathrm{N} \mathrm{L}{ }^{-1}$. The specific ANAMMOX activity was found to be $0.598 \pm$ $0.026 \mathrm{gN}_{2}-\mathrm{N} \mathrm{gVSS}^{-1} \mathrm{~d}^{-1}$. Analysis of ANAMMOX granules suggested that $0.5-1.0 \mathrm{~mm}$ size granular sludge was the dominant group. The results of DNA analysis revealed that Candidatus Kueneniastuttgartiensis was the dominant species $(37.45 \%)$ in the IC reactor, whereas other species like uncultured Bacteroidetes bacterium only constituted $5.37 \%$ in the system, but they were still responsible for removing recalcitrant organic matter.

Keywords: Leachate, IC; ANAMMOX, Nitrogen removal and granular sludge 


\section{Introduction}

Old landfill leachates are referred to as wastewater and their treatment is very complicated and costly due to high loads of refractory organic compounds, low $\mathrm{BOD}_{5} / \mathrm{COD}$ ratio, high salinity and ammonia. The concentration of ammonia in leachate increases gradually according to the age of landfill leachate, which can turn into a serious environmental problem and make waste management difficult (Renou et al., 2008; Sri Shalini and Joseph, 2012). Partial nitritation (PN) followed by the ANAMMOX process may represent a good alternative to the conventional nitrification-denitrification process for nitrogen removal (van Dongen et al., 2001; Fux et al., 2002; Schmidt et al., 2003). The advantages of this process are that it consumes $50 \%$ less oxygen, requires no external organic carbon, has less sludge and results in lower carbon dioxide emissions (Reginatto et al., 2005). The PN and ANAMMOX processes were successfully conducted in single reactors or in two consecutive reactors (Jetten et al., 1998; van Dongen et al., 2001). In the case of high influent TKN concentration, the separated two-step process is preferred because it promotes ANAMMOX bacterial activity and suppresses heterotrophic bacterium growth in the reactor (Van Hulle et al., 2007). This combined PN-ANAMMOX process was investigated in previous studies at low nitrogen loading rates, which ranged from 0.17 to $0.96 \mathrm{~kg} \mathrm{~N} \mathrm{~m}^{-3} \mathrm{~d}^{-1}$ (Liang and Liu, 2008; Liu et al., 2010; Ruscalleda et al., 2010; Wang et al., 2010; Xu et al., 2010). A more recent analysis indicated that an ANAMMOX reactor operated for a long period of time was only stably run under nitrogen loading rate of $1 \mathrm{~kg} \mathrm{~N} \mathrm{~m}^{-3} \mathrm{~d}^{-1}$ and $85 \pm 1 \%$ of nitrogen removal. In this study Kuenenia Stuttgartiensis affiliates served as the dominated species (Li et al., 2014).

In fact, to date ANAMMOX granules have not been widely studied but there is some evidence that removing $50 \%$ of nitrogen can be achieved at extremely high nitrogen loading rate of $50-60 \mathrm{~kg} \mathrm{~N} \mathrm{~m}^{-3} \mathrm{~d}^{-1}$ in a high rate ANAMMOX UASB reactor (Tang et al., 2014). Moreover, a few studies have reported that concentrations of $\mathrm{Ca}(\mathrm{II})$ and $\mathrm{Fe}(\mathrm{II})$ in feeding 
wastewater can have an impact on intracellular chemical composition as well as bacterial activity (Liu et al., 2013; Qiao et al., 2013). Based on the settling properties of ANAMMOX granular sludge as documented in other studies, granules with a diameter of $1.75-2.20 \mathrm{~mm}$ were ideal for the ANAMMOX process because they avoided floatation ( $\mathrm{Lu}$ et al., 2012 \& 2013).

A few years ago, we developed a model called the hybrid ANAMMOX reactor (HAR) which removed nitrogen from leachate. However, operating this reactor presented some disadvantages: a) the small formation of granular sludge which entailed the highest influent nitrogen loading rate of $8 \mathrm{kgN} \mathrm{m}^{-3} \mathrm{~d}^{-1}$; and b) the appearance of sludge clogging up the effluent when the reactor operated for a long period of time. To overcome the above drawbacks, a novel reactor known as ANAMMOX internal circulation reactor (IC) was introduced in this study and the performance of this high rate nitrogen removal IC reactor for old landfill leachate treatment was evaluated.

Due to the slow growth rate of the Anammox bacteria, the reactors are usually operated at an extremely long sludge retention time in order to cultivate the bacteria successfully. In the free cell or flocculent sludge Anammox systems, the cultured biomass is easily to be washed out. In addition, Anammox bacteria have a trend to grow in aggregates, high-rate granule system was considered to be one of the suitable and promising methods for Anammox process (Tang et al., 2014). Previous study postulated that IC-granules are larger than UASB-granules grown on similar wastewater, while the strength of IC-granules is lower as a result of the higher sludge loading rate. The IC reactor is an anaerobic sludge bed reactor constructed in the form of tall cylindrical vessel. It uses an internal circulation based on airlift principle, generated by the biogas that is produced inside the reactor. Optimal biomass retention is provided by a twostage separator. The first stage separates the majority of the biogas from the water, so that the second stage mainly separates the active biomass from the treated effluent. Internal Circulation (IC) reactors can be operated at higher volume loading rates than UASB reactors. 
The two-stage design of the IC-reactor allows 3-6 times higher applied loading rate. Although wash-out is slightly enhanced in IC-reactors, the conditions in the second stage are tranquil enough to ensure adequate biomass retention in IC-reactors. This internal circulation ensures dilution of the raw influent and ensures optimal mixing conditions for the anaerobic granular sludge and the wastewater. Furthermore, the liquid upflow velocity is 8-20 times higher and the average shear rate in IC reactors is approximately twice as high compared to UASB reactors, still granules develop successfully in IC-reactors. That is the main things that makes the anammox granular sludge improve good mixing conditions and reduce the sludge clogging in the IC (Pereboom and Vereijken, 1994). The performance of the Anammox process is enhanced by the use of appropriate effluent recirculation with other positive operation conditions. The characteristics of recycled effluent were close to the interior water conditions of the Anammox system, which improved the nitrogen elimination efficiency and process stability. The appropriate rate of circulation of 1.0-1.7 helped maintain circulation velocity in the IC that improve anammox granular formation (Jin et al., 2012).”

\section{Materials and Methods}

\subsection{Internal Circulation Reactor}

The Internal Circulation (IC) reactor was made of acrylic tubes with a total volume of 13.8 litres and working volume of 10 litres. The reactor was $1,450 \mathrm{~mm}$ in height and $100 \mathrm{~mm}$ in diameter. The granules were mixed with feed leachate by flowing from a downpipe that circulated flow in the lower compartment. The leachate moved from the lower compartment to the upper compartment. This resulted in stratification of granular sludge in the upper compartment. Adequate up-flow velocity and shear stress were maintained in favour of granule formation, reduction of sludge washout and negative effects of high nitrite concentration on ANAMMOX bacteria growth. A three-phase funnel separator at the top of 
the reactor served to collect the resultant nitrogen gas. The schematic diagram of IC is presented in Figure 1.

\section{Insert Figure 1}

\subsection{Leachate and ANAMMOX sludge}

Landfill leachate used in this study was collected from Go Cat municipal solid waste landfill which is located in Ho Chi Minh City, Vietnam. The landfilling for this landfill was completed in 2007. The feed leachate was pre-treated using a pilot Partial Nitritation Reactor (PNR), which was run at the same time as the ANAMMOX reactor. The PNR was run at nitrogen loading rates (NLR) of $0.8-0.9 \mathrm{~kg} \mathrm{~N} \mathrm{~m}^{-3} \mathrm{~d}^{-1}$ and initial ammonia concentration of 2,830-3,096 $\mathrm{mg} \mathrm{N} \mathrm{L}^{-1}$. The effluent of the PNR obtained ammonia:nitrite ratios ranging from 0.9 to 1.35 and contained COD of $1,565 \pm 102 \mathrm{mg} \mathrm{L}^{-1}$. The feed leachate was PNR effluent diluted with tap water to obtain the influent ammonia and nitrite concentration varying between 235-655 $\mathrm{mg} \mathrm{N} \mathrm{L}^{-1}$ and 261-858 $\mathrm{mg} \mathrm{N} \mathrm{L}^{-1}$, respectively. The PNR effluent did not reach the ammonia:nitrite ratio of $1.00-1.35$, so $\mathrm{NH}_{4} \mathrm{Cl}$ and $\mathrm{NaNO}_{2}$ salts were added.

The feed sludge was taken from the hybrid ANNAMOX reactor used in a previous study (Nhat et al. 2014). $65 \mathrm{~g} \mathrm{VS}$ of the feed sludge, equivalent to $6,500 \mathrm{mg} \mathrm{VSS} \mathrm{L}^{-1}$ and $13,000 \mathrm{mg}$ $\mathrm{SS} \mathrm{L}^{-1}$ was seeded into the IC.

\subsection{Operating conditions}

The IC experiment lasted 280 days at an ambient temperature ranging from 25 to $30^{\circ} \mathrm{C}$. The experiment comprised 5 phases, corresponding to different NLR ranging from 2 to $10 \mathrm{~kg} \mathrm{~N} \mathrm{~m}^{-}$ ${ }^{3} \mathrm{~d}^{-1}$. The operating conditions are shown in Table 1 . 
Insert Table 1

During the operation phase, $\mathrm{pH}$ of the feed leachate was manually adjusted in the $6.8-7.2$ range using $10 \% \mathrm{HCl}$ solution. The experiment was conducted under dark conditions using a black plastic sheet fully enclosing the reactor body to prevent algae growth. $\mathrm{Na}_{2} \mathrm{SO}_{3}$ salt was added into the PN-SBR effluent tank to reduce DO to less than $0.5 \mathrm{mg} \mathrm{L}^{-1}$.

\subsection{Specific ANAMMOX Activity}

The specific ANAMMOX activity (SAA) was determined by a manometric method adapted from another research analysis (Dapena-Mora et al., 2007). Batch assays were performed in $120 \mathrm{~mL}$ glass vials ( $57 \mathrm{~mL}$ of actual volume) sealed with a rubber septum. The experiment lasted $4-4.5$ hours, with mixing at $150 \mathrm{rpm}$ and $\mathrm{DO}<0.1 \mathrm{mg} \mathrm{L}^{-1}$. A differential pressure sensor (Omron, Japan) was used to measure pressure; the average error in pressure measurement was less than 5\%. The granular sludge collected from the IC reactor and used for batch tests was previously washed and re-suspended in mineral solutions according to the research of Dapena-Mora et al. (2007).

\subsection{ANAMMOX sludge characteristics}

Granular ANAMMOX sludge was characterized by assessment of trace metals, phosphorous content, settling velocity, specific gravity versus the size of granules and granule size distribution. Three $100 \mathrm{~mL}$ samples of ANAMMOX granular sludge that were taken at different heights of the IC reactor were mixed together. The granules obtained were then sieved through four sieves with different meshes $(0.5 \mathrm{~mm}, 1 \mathrm{~mm}, 2 \mathrm{~mm}$ and $3 \mathrm{~mm})$. Trace metals including $\mathrm{Ca}, \mathrm{Mg}$ and $\mathrm{Fe}$ and phosphorous in the destroyed sludge were determined 
according to standard methods (APHA et al., 1999). The sludge destruction procedure was based on EPA Method 200.7 (1994). The physical characteristics of the ANAMMOX sludge consisting of specific gravity and settling velocity, were measured according the method employed in a previous study (Zheng et al., 2005). The granule size distribution was determined by a Laser Scattering Particle Size Distribution Analyser LA-950 (HORIBA, Japan). This method measures sludge samples smaller than $3.0 \mathrm{~mm}$ in size. To remove granules larger than $3.0 \mathrm{~mm}$, the sludge sample was sieved using a $3.0 \mathrm{~mm}$ mesh sieve.

\subsection{DNA extraction and PCR amplication}

The granular sludge sample originated from the IC reactor. Metagenomic DNA was extracted from the granular biomass using FasDNA Spin kit for Soil (MP Biomedicals, OH, USA), according to the instruction manual. The amplication of $16 \mathrm{~S}$ rRNA gene was done at the Macrogen Company laboratory using V34 primer variable region forward primer:

\section{5' TCGTCGGCAGCGTCAGATGTGTATAAGAGACAGCCTACGGGNGGCWGCAG}

(ref.) and reverse primer

\section{GTCTCGTGGGCTCGGAGATGTGTATAAGAGACAGGACTACHVGGGTATCTAATCC}

-3 '. Polymerase chain reaction (PCR) was carried out at the Macrogen Co. The set-up the reaction of DNA includes $2.5 \mu \mathrm{l}$ of Microbial DNA $5 \mathrm{ng} \mu \mathrm{l}^{-1}, 5 \mu \mathrm{l}$ of Amplion PCR Forward Primer $1 \mu \mathrm{M}, 5 \mu \mathrm{l}$ of Amplion PCR Reverse Primer $1 \mu \mathrm{M}$ and $12.5 \mu \mathrm{l}$ of $2 \mathrm{X} \mathrm{KAPA} \mathrm{HiFi}$

HotStart ReadyMix PCR kit. Total volume was $25 \mu \mathrm{l}$. PCR was executed in a thermal cycler using the following program: 3 minutes for initial denaturation at $95^{\circ} \mathrm{C}, 25$ cycles of $30 \mathrm{~s}$ at $95^{\circ} \mathrm{C}, 30 \mathrm{~s}$ at $55^{\circ} \mathrm{C}, 30 \mathrm{~s}$ at $72^{\circ} \mathrm{C}$, and then 5 minutes at final elongation at $72^{\circ} \mathrm{C}$. The amplicon DNAs were performed using PCR clean-up, 2nd stage PCR, PCR Clean-Up 2 and finally Library Quantification and Normalization as described in the 16S Library Preparation Workflow (Figure 2). Raw sequences were then filtered, aligned and clustered at 0.03 
distances using the furthest algorithm to generate operational taxonomic units (OTUs). OTUs were then classified using the same database from Mothur software package Version 1.34.3). OTUs of dominant groups were then classified again using the Blast (online database) for finding the closest matches.

Insert Figure 2

\subsection{Analytical methods}

pH and DO were measured using a pH meter (HI 8314, Hanna) and DO meter (InoLab 740, WTW, Germany), respectively. Determination of nitrogen species including ammonia, nitrite and nitrate was conducted according to standard methods (APHA et al., 1999).

\section{Results and discussion}

\subsection{Performance of IC reactor}

Concentrations of nitrogen species in the influent and effluent with time is presented in Figure 3.

Insert Figure 3

During phase I (day 1 - 28), the nitrite removal efficiency (NRE) progressively increased from $46 \%$ on day 1 to $96 \%$ on day 18 , reaching a peak of $100 \%$ on day 25 . The average total nitrogen removal rate (NRR) was $1.70 \pm 0.44 \mathrm{~kg} \mathrm{~N} \mathrm{~m}^{-3} \mathrm{~d}^{-1}$. During this phase, the influent nitrate fluctuated between 30 and $57 \mathrm{mg} \mathrm{N} \mathrm{L}^{-1}$, corresponding to $5.9 \%$ and $8.9 \%$ of influent total nitrogen, respectively. Despite the rise of NLR to $4.0 \pm 0.04 \mathrm{~kg} \mathrm{~N} \mathrm{~m}^{-3} \mathrm{~d}^{-1}$, the NRE of $80 \%$ was observed on the first day of phase II (day 29 - 45). The high removal efficiency indicates that the ANAMMOX bacteria had the ability to adapt to and resist the loading shock 
at higher NLR, with considerable NRR of $3.83 \pm 0.20 \mathrm{~kg} \mathrm{~N} \mathrm{~m}^{-3} \mathrm{~d}^{-1}$. The effluent concentrations of ammonia and nitrite nitrogen were always under detection limits at the end of this phase. Insignificant differences between phase I and phase II with reference to influent nitrate were found and nitrate nitrogen was in the range of $31-55 \mathrm{mg} \mathrm{N} \mathrm{L}^{-1}$. During phase III (day $46-70$ ), the total influent nitrogen concentration increased from $528 \pm 19 \mathrm{mg} \mathrm{N} \mathrm{L}^{-1}$ to $809 \pm 12 \mathrm{mg} \mathrm{N} \mathrm{L}^{-1}$ while NLR increased from $4.0 \pm 0.04 \mathrm{~kg} \mathrm{~N} \mathrm{~m}^{-3} \mathrm{~d}^{-1}$ to $6.0 \pm 0.09 \mathrm{~kg} \mathrm{~N} \mathrm{~m}^{-3} \mathrm{~d}^{-}$ , which is equivalent to NRR of $5.17 \pm 0.48 \mathrm{~kg} \mathrm{~N} \mathrm{~m}^{-3} \mathrm{~d}^{-1}$ after 25 days of operation.

Furthermore, the effluent nitrate concentration ( $39 \mathrm{mg} \mathrm{N} / \mathrm{L})$ was less than the theoretical value (90 mgN/L). This may be due to the coexistence of denitrification and the ANAMMOX process. Phase IV (day $71-87$ ) started at slightly lower NRE (76\%) due to a sudden increase in influent total nitrogen concentration to $1,290 \pm 9 \mathrm{mg} \mathrm{N} \mathrm{L}^{-1}$, corresponding to NLR to $8.0 \pm$ $0.06 \mathrm{~kg} \mathrm{~N} \mathrm{~m}^{-3} \mathrm{~d}^{-1}$. However, a rapid increase of NRE to $93 \%$ was observed on day 9 of phase IV and NRE of $100 \%$ after day 13 . Thus, the IC performed excellently with average NRR of approximately $7.00 \pm 0.86 \mathrm{~kg} \mathrm{~N} \mathrm{~m}^{-3} \mathrm{~d}^{-1}$.

Long-term steady operation of IC with very high NRR of $9.52 \pm 1.11 \mathrm{~kg} \mathrm{~N} \mathrm{~m}^{-3} \mathrm{~d}^{-1}$ was obtained at NLR of $10.0 \pm 0.04 \mathrm{~kg} \mathrm{~N} \mathrm{~m}^{-3} \mathrm{~d}^{-1}$ in Phase V (day $87-280$ ), whereas other studies only ran at NLR under $1 \mathrm{~kg} \mathrm{~N} \mathrm{~m}^{-3} \mathrm{~d}^{-1}$ (Liang and Liu, 2008; Liu et al., 2010; Ruscalleda et al., 2010; Wang et al., 2010; Xu et al., 2010). In addition, a recent study concerning old leachate treatment showed that HAR achieved NRR of $6.7 \mathrm{~kg} \mathrm{~N} \mathrm{~m}^{-3} \mathrm{~d}^{-1}$ (Nhat et al., 2014). However, at high NLR, the HAR encountered clogging by the sludge which limited substrate diffusion and caused the ANAMMOX biomass to decay. Nearly complete removal of nitrogen (ammonia and nitrite) was found after 28 days of this phase. On day 118, a significant decline in nitrogen removal was observed due to high influent $\mathrm{pH}(8.2)$, which was caused by no $\mathrm{pH}$ adjustment. In order to recover the ANAMMOX activity, the PN-treated leachate was diluted with tap water in order to gradually increase nitrogen concentration (from 200 - 1,500 mg N $\mathrm{L}^{-1}$ ). It took a recovery process lasting 22 days for it to reach a level of stable performance 
(NRE of 99\%) at NLR of $10.0 \pm 0.04 \mathrm{~N} \mathrm{~m}^{-3} \mathrm{~d}^{-1}$. Another problem occurred on day 178, that the faulty effluent recirculating pump created a high nitrite concentration in the bottom compartment, causing inhibition of ANAMMOX bacteria. Troubleshooting of this problem was similar to that on day 118 . After 5 days, the IC was completely recovered.

\subsection{Specific ANAMMOX activity}

\section{Insert Table 2}

Ammonium and nitrite are the main substrates for Anammox bacteria so the increase in availability of these substrates in the reactor should increase the activity of bacteria because of enhancing the diffusion both into the depth of biofilm and through cell membrane of bacteria. Specific Anammox activity (SAA) is defined as transformation of nitrogen from different forms into nitrogen gas. The granular ANNAMOX sludge characterized by high activity plays a pivotal role in the performance of high-rate bioreactors. When the maximum specific activity was exceeded, the system became unstable and biomass started to float (DapenaMora et al., 2007).

In addition, the common methodological approaches adopted to detect, identify and confirm ANAMMOX bacteria or their activity includes (a) Chemical analyses of the nitrogen compounds to detect the change in the concentrations of $\mathrm{NH}_{4}-\mathrm{N}, \mathrm{NO}_{2}{ }^{-}-\mathrm{N}^{-}$and $\mathrm{NO}_{3}{ }^{-}-\mathrm{N}$ owing to ANAMMOX activity (showed in section 3.1 in this study); (b) Application of molecular techniques such as Polymerase Chain Reaction (PCR), which are based on the nucleic acid analysis for identification. A number of specific sequences and primers were developed to amplify the 16S rRNA from the environmental and enrichment samples using the PCR based approach (showed section 3.4 in this study). 
Table 2 shows the SAA value of the study was higher than those of other studies. This proves that ANAMMOX bacteria have the ability to adapt, grow and thrive in the IC reactor with old leachate feeding."

\subsection{ANAMMOX sludge characteristics}

The sludge profile is presented in Figure 4. The initial sludge concentration of $13,000 \mathrm{mg} \mathrm{SS}$ $\mathrm{L}^{-1}$ was seeded at the beginning. On day 280 , sludge concentrations at the bottom, middle and top of IC were $66,530 \pm 1,960 \mathrm{mg} \mathrm{MLSS} \mathrm{L}^{-1}, 60,499 \pm 5,793 \mathrm{mg} \mathrm{MLSS} \mathrm{L}^{-1}$ and 59,016 \pm 2,732 $\mathrm{mg} \mathrm{MLSS} \mathrm{L}^{-1}$, respectively (Figure 4). It was found that the MLVSS:MLSS ratio and SVI of the reactor were $0.57 \pm 0.01$ and $9.92 \pm 0.93 \mathrm{ml} \mathrm{g}^{-1}$, respectively. Table 3 shows characteristics of ANAMMOX sludge.

\section{Insert Figure 4}

\section{Insert Table 3}

The granule distribution values were calculated based on the results from the laser scattering particle size distribution analyser shown in Figure 5. It emerged that the diameter of the dominant ANAMMOX granules in IC reactor ranged from 0.5 to $1 \mathrm{~mm}$, which accounted for $58 \%$ of the total number of particles and $35 \%$ of the total mass. The settling velocity of the dominated granules $\left(2.03 \mathrm{~cm} \mathrm{~s}^{-1}\right)$ was in the range of the efficient settling velocity of ANAMMOX sludge $\left(2.0\right.$ and $\left.2.4 \mathrm{~cm} \mathrm{~s}^{-1}\right)$ in terms of bacteria growth and activity promotion (Tang et al., 2011). Moreover, the VSS:SS ratio of 0.63 and the Fe content of $11.7 \mathrm{mg} \mathrm{Fe}$ $\mathrm{gVSS}^{-1}$ were the highest values compared to the other granule sizes. In other research, Huang et al. (2014) reported that ferrous was the determining factor in nitrogen removal efficiency and granules of $0.5-1.0 \mathrm{~mm}$ size could be maintained for maximum performance. Calcium 
concentration, magnesium concentration and density of these ANAMMOX granules, were $180 \mathrm{mgCa} \mathrm{gVSS}^{-1}, 9.5 \mathrm{mgMg} \mathrm{gVSS}^{-1}$ and $1.05-1.06 \mathrm{~g} \mathrm{~cm}^{-3}$, respectively.

\section{Insert Figure 5}

\subsection{DNA Analysis}

\section{Insert Table 4}

The purpose of analysing the microbial community by 16S rRNA using 16S V3 and V4 regions were to investigate the microbial community structure of IC granular sludge. 35409 sequences were obtained and these were grouped into 156 representative OTUs.

Results shows that the most dominant population was closely related to Candidatus Kueneniastuttgartiensis (37.45\%), which has also been reported in previous studies (Furukawa et al., 2002; Li et al., 2014). Apart from this, although uncultured Bacteroidetes bacterium had a very low relative abundance (RA) of 5.37\%, this population played a key role in degrading refractory organic matter, particularly decaying aquatic humic substances (AHS) and removing volatile fatty acids (VFAs) (Liang and Liu, 2008). Indeed, this result was identical to the results reported in Nhat et al. (2014).

The ANAMMOX bacteria outnumbered other bacteria in the reactor can be explained as follows. The feed leachate into the IC was pre-treated using a pilot Partial Nitritation Reactor (PNR). The influent has the ratios of $\mathrm{NO}_{2}-\mathrm{N} / \mathrm{NH}_{4}-\mathrm{N}=1.0-1.3$ that suitable for the growth of anammox bacteria under anaerobic condition. Moreover, old leachate after the partial nitritation process contains very low biodegradable COD. Under these conditions, denitrifiers 
grow very limited due to lack of rapid biodegradable COD. The most dominant population was closely related to Candidatus Kueneniastuttgartiensis $(37.45 \%$, in this study). In addition, ANAMMOX population was related to Kueneniastuttgartiensis and Brocadia anammoxidans. Besides some other bacteria were also identified Cytophaga, Flavobacterium, bacteroides, etc. (Schmid et al., (2001).

\section{Conclusions}

The results of this study demonstrated that the use of an IC reactor running at very high NLR of $10 \mathrm{~kg} \mathrm{~N} \mathrm{~m}^{-3} \mathrm{~d}^{-1}$ proved to be a feasible method for removing nitrogen from old landfill leachate. The ANAMMOX granules with a diameter ranging from $0.5-1.0 \mathrm{~mm}$ demonstrated to be the best performing and dominating group. Furthermore, the PCR data revealed that the ANAMMOX bacteria outnumbered other bacteria in the reactor with relative abundance (RA) of about $37.45 \%$.

\section{Acknowledgements}

This research was funded by Vietnam National University Ho Chi Minh City (VNU-HCM) under grant number B2016-20-06. The authors deeply thank the research staff at Yonsei University (Korea) for analysis of the bacterial community. This study has been conducted under the framework of CARE-RESCIF initiative. The authors are also grateful for the research collaboration between VNU-HCM and University of Technology Sydney (UTS).

\section{References}

1. APHA, AWWA, WEF, 1999. Standard Methods for the Examination of Water and Wastewater, Standard Methods for the Examination of Water and Wastewater. 
2. Bae, H., Chung, Y.C., Jung, J.Y. 2010. Microbial community structure and occurrence of diverse autotrophic ammonium oxidizing microorganisms in the anammox process. Water Sci. Technol. 61, 2723-2732.

3. Dapena-Mora, A., Fernandez, I., Campos, J.L., Mosquera-Corral, A., Mendez, R., Jetten, M.S.M., 2007. Evaluation of activity and inhibition effects on Anammox process by batch tests based on the nitrogen gas production. Enzyme Microb. Technol. 40, 859-865.

4. EPA method 200.7, 1994. Determination of metals and trace elements in water and wastes by inductively coupled plasma-atomic emission spectrometry.

5. Furukawa, K., Rouse, J.D., Imajo, U., Nakamura, K., Isahida, H., 2002. Anaerobic Oxidation of Ammonium Confirmed in Continuous Flow Treatment Using a Non-woven Biomass Carrier. Japanese J. Water Treat. Biol. 38, 87-94.

6. Fux, C., Boehler, M., Huber, P., Brunner, I., Siegrist, H., 2002. Biological treatment of ammonium-rich wastewater by partial nitritation and subsequent anaerobic ammonium oxidation (anammox) in a pilot plant. J. Biotechnol. 99, 295-306.

7. Huang, X., Gao, D., Peng, S., Tao, Y., 2014. Effects of ferrous and manganese ions on anammox process in sequencing batch biofilm reactors. J. Environ. Sci. (China). 26, 1034-1039.

8. Jetten, M.S.M., Strous, M., Van De Pas-Schoonen, K.T., Schalk, J., Van Dongen, U.G.J.M., Van De Graaf, A.A., Logemann, S., Muyzer, G., Van Loosdrecht, M.C.M., Kuenen, J.G., 1998. The anaerobic oxidation of ammonium. FEMS Microbiol. Rev. 22, 421-437.

9. Jin, R.C., Yang, G.F., Ma, C., Yu, J.J., Zhang, Q.Q., \& Xing, B.S., 2012. Influence of effluent recirculation on the performance of Anammox process. Chem. Eng. J. 200, 176185.

10. Lane, D.J., 1991. 16S/23S rRNA Sequencing. In: Nucleic Acid Techniques in Bacterial Systematic. Wiley, New York. 
11. Li, H., Zhou, S., Ma, W., Huang, P., Huang, G., Qin, Y., Xu, B., Ouyang, H., 2014. Longterm performance and microbial ecology of a two-stage PN-ANAMMOX process treating mature landfill leachate. Bioresour. Technol. 159, 404-411.

12 Liang, Z., Liu, J., 2008. Landfill leachate treatment with a novel process: Anaerobic ammonium oxidation (Anammox) combined with soil infiltration system. J. Hazard. Mater. 151, 202-212.

13. Liu, J., Zuo, J., Yang, Y., Zhu, S., Kuang, S., Wang, K., 2010. An autotrophic nitrogen removal process: Short-cut nitrification combined with ANAMMOX for treating diluted effluent from an UASB reactor fed by landfill leachate. J. Environ. Sci. 22, 777-783.

14. Liu, S., Zhang, Z., Ni, J., 2013. Effects of Ca2+ on activity restoration of the damaged anammox consortium. Bioresour. Technol. 143, 315-321.

15. Lotti, T., van der Star, W.R.L., Kleerebezem, R., Lubello, C., van Loosdrecht, M.C.M., 2012. The effect of nitrite inhibition on the anammox process. Water Res. 46, 25592569.

16. Lu, H., Ji, Q., Ding, S., Zheng, P., 2013. The morphological and settling properties of ANAMMOX granular sludge in high-rate reactors. Bioresour. Technol. 143, 592-597.

17. Lu, H.-F., Zheng, P., Ji, Q.-X., Zhang, H.-T., Ji, J.-Y., Wang, L., Ding, S., Chen, T.-T., Zhang, J.-Q., Tang, C.-J., Chen, J.-W., 2012. The structure, density and settlability of anammox granular sludge in high-rate reactors. Bioresour. Technol. 123, 312-317.

18. Nhat, P.T., Biec, H.N., Tuyet Mai, N.T., Thanh, B.X., Dan, N.P., 2014. Application of a partial nitritation and anammox system for the old landfill leachate treatment. Int. Biodeterior. Biodegradation 95, 144-150.

19. Pajares, S., Souza, V., Eguiarte, L.E. 2015. Multivariate and phylogenetic analyses assessing the response of bacterial mat communities from an ancient oligotrophic aquatic ecosystem to different scenarios of long-term environmental disturbance. PLoS One 10(3), e0119741. 
20. Park, H., Rosenthal, A., Ramalingam, K., Fillos, J., Chandran, K. 2010. Linking community profiles, gene expression and N-removal in anammox bioreactors treating municipal anaerobic digestion reject water. Environ Sci. Technol. 44, 6110-6116.

21. Pereboom, H.F. and Vereijken, T.L.F.M., 1994. Methanogenic granule development in full scale internal circulation reactors. Wat. Sci. Tech. 30, 9-21.

22. Qiao, S., Bi, Z., Zhou, J., Cheng, Y., Zhang, J., 2013. Long term effects of divalent ferrous ion on the activity of anammox biomass. Bioresour. Technol. 142, 490-497.

23. Reginatto, V., Teixeira, R.M., Pereira, F., Schmidell, W., Furigo, A., Menes, R., Etchebehere, C., Soares, H.M., 2005. Anaerobic ammonium oxidation in a bioreactor treating slaughterhouse wastewater. Brazilian J. Chem. Eng. 22, 593-600.

24. Renou, S., Givaudan, J.G., Poulain, S., Dirassouyan, F., Moulin, P., 2008. Landfill leachate treatment: Review and opportunity. J. Hazard. Mater. 150, 468-493.

25. Ruscalleda, M., Puig, S., Mora, X., López, H., Ganigué, R., Balaguer, M.D., Colprim, J., 2010. The effect of urban landfill leachate characteristics on the coexistence of anammox bacteria and heterotrophic denitrifiers, Water Sci. Technol. 1065-1071.

26. Ruscalleda (2011), Treatment of mature urban landfill leachates by Anammox process, Ph. D. Thesis, University of Girona, Spain.

27. Scaglione, D., Ruscalleda, M., Ficara, E., Balaguer, M.D., Colprim, J., 2012. Response to high nitrite concentrations of anammox biomass from two SBR fed on synthetic wastewater and landfill leachate. Chem. Eng. J. 209, 62-68.

28. Schmid, M., Schmitz-Esser, S., Jetten, M., Wagner, M. 2001. 16S-23S rDNA intergenic spacer and 23S rDNA of anaerobic ammonium-oxidizing bacteria: implications for phylogeny and in situ detection. Environ. Microbio. 3, 450-459.

29. Schmidt, I., Sliekers, O., Schmid, M., Bock, E., Fuerst, J., Kuenen, J.G., Jetten, M.S.M., Strous, M., 2003. New concepts of microbial treatment processes for the nitrogen removal in wastewater. FEMS Microbiol. Rev. 27, 481-492. 
30. Sri Shalini, S., Joseph, K., 2012. Nitrogen management in landfill leachate: application of SHARON, ANAMMOX and combined SHARON-ANAMMOX process. Waste Manag. $32,2385-400$.

31. Sun, J., Zhang, Y., Liu, G., Ning, X., Wang, Y., Liu, J. 2015. Unveiling characteristics of a bioelectrochemical system with polarity reversion for simultaneous azo dye treatment and bioelectricity generation. Appl Microbiol Biotechnol. 99, 7295-305.

32. Tang, C.-J., Zheng, P., Ding, S., Lu, H.-F., 2014. Enhanced nitrogen removal from ammonium-rich wastewater containing high organic contents by coupling with novel high-rate ANAMMOX granules addition. Chem. Eng. J. 240, 454-461.

33. Tang, C.J., Zheng, P., Wang, C.H., Mahmood, Q., Zhang, J.Q., Chen, X.G., Zhang, L., Chen, J.W., 2011. Performance of high-loaded ANAMMOX UASB reactors containing granular sludge. Water Res. 45, 135-144.

34. Tchelet, R., Meckenstock, R., Steinle, P., Van Der Meer, J.R., 1999. Population dynamics of an introduced bacterium degrading chlorinated benzenes in a soil column and in sewage sludge. Biodegradation 10,113-125.

35. Van Dongen, U., Jetten, M.S., van Loosdrecht, M.C., 2001. The SHARON-Anammox process for treatment of ammonium rich wastewater. Water Sci. Technol. 44, 153-60.

36. Van Hulle, S.W.H., Volcke, E.I.P., Teruel, J.L., Donckels, B., van Loosdrecht, M.C.M., Vanrolleghem, P.A., 2007. Influence of temperature and $\mathrm{pH}$ on the kinetics of the Sharon nitritation process. J. Chem. Technol. Biotechnol. 82, 471-480.

37. Wang, C.C., Lee, P.H., Kumar, M., Huang, Y.T., Sung, S., Lin, J.G., 2010. Simultaneous partial nitrification, anaerobic ammonium oxidation and denitrification (SNAD) in a fullscale landfill-leachate treatment plant. J. Hazard. Mater. 175, 622-628.

38. Xu, Z.Y., Zeng, G.M., Yang, Z.H., Xiao, Y., Cao, M., Sun, H.S., Ji, L.L., Chen, Y., 2010. Biological treatment of landfill leachate with the integration of partial nitrification, 
anaerobic ammonium oxidation and heterotrophic denitrification. Bioresour. Technol. $101,79-86$.

39. Zheng, Y.-M., Yu, H.-Q., Sheng, G.-P., 2005. Physical and chemical characteristics of granular activated sludge from a sequencing batch airlift reactor. Process Biochem. 40, $645-650$. 


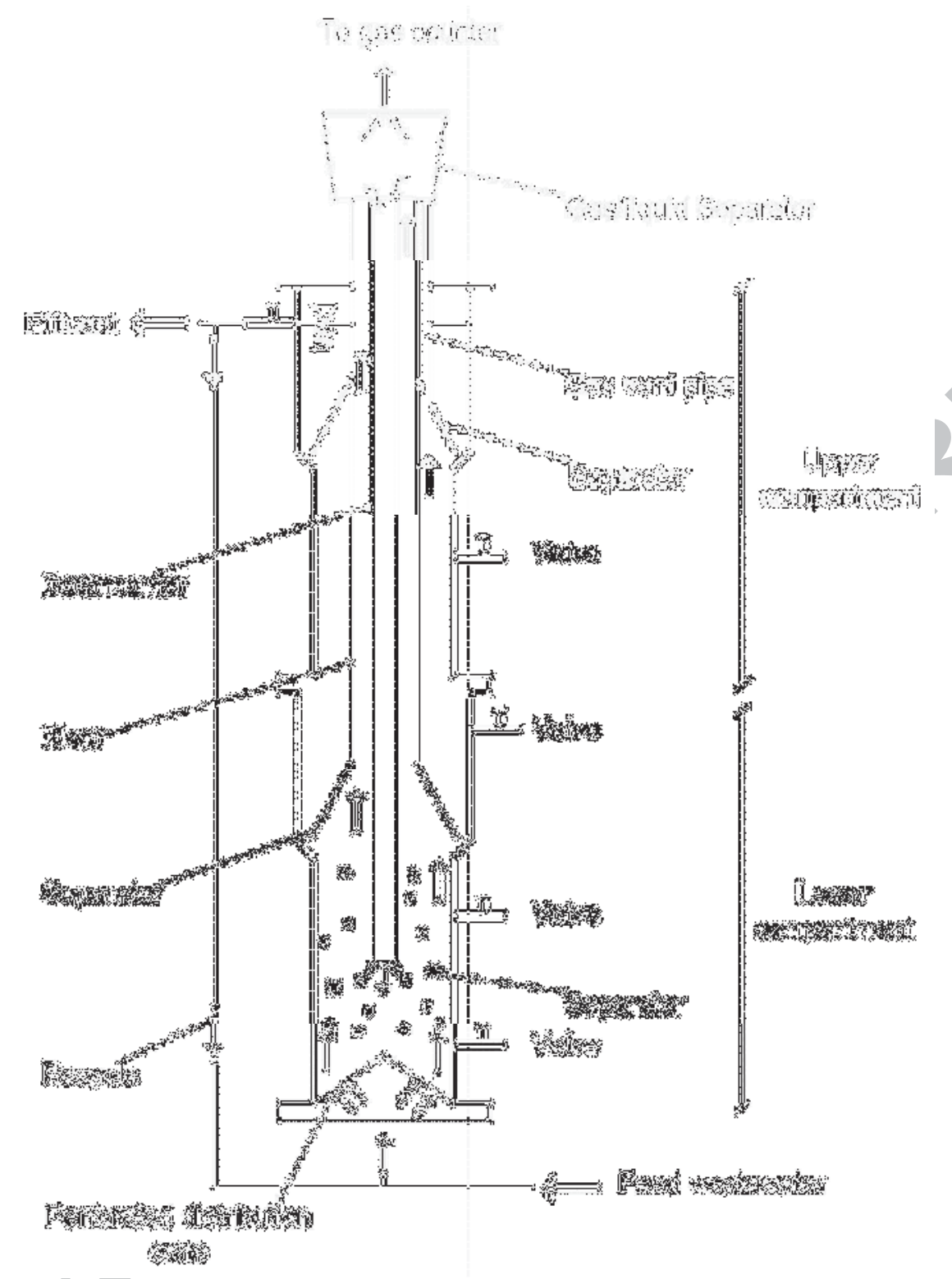

Figure 1. Schematic diagram of ANAMMOX IC reactor 


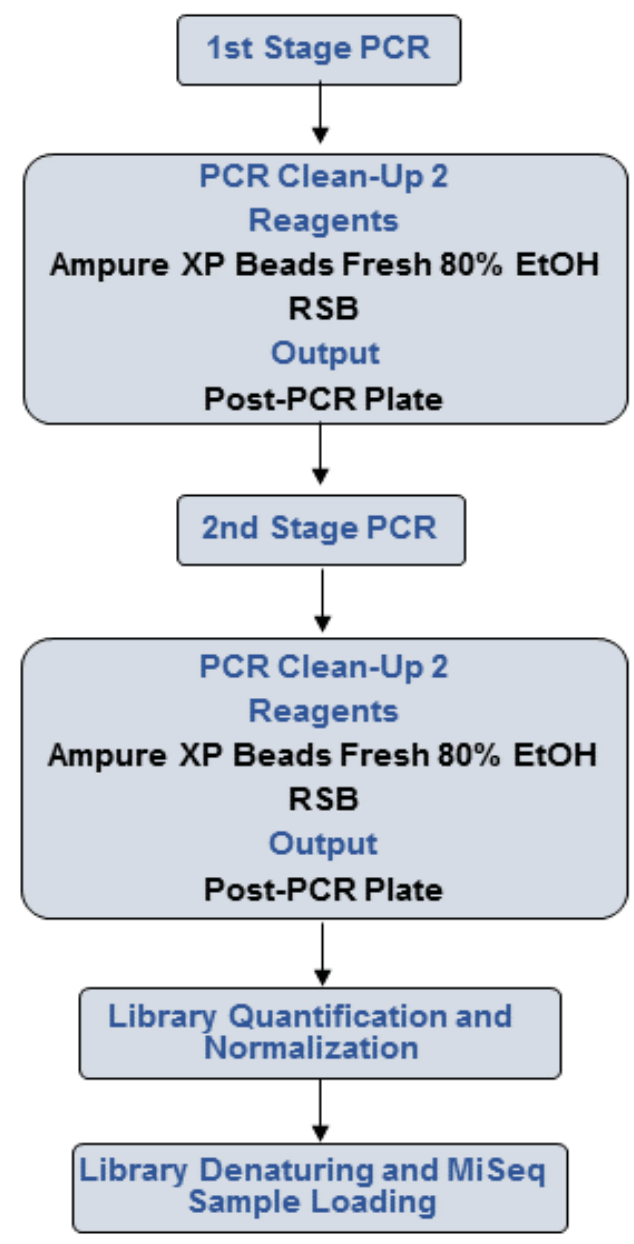

Figure 2.16S Library preparation workflow 


\section{ACCEPTED MANUSCRIPT}

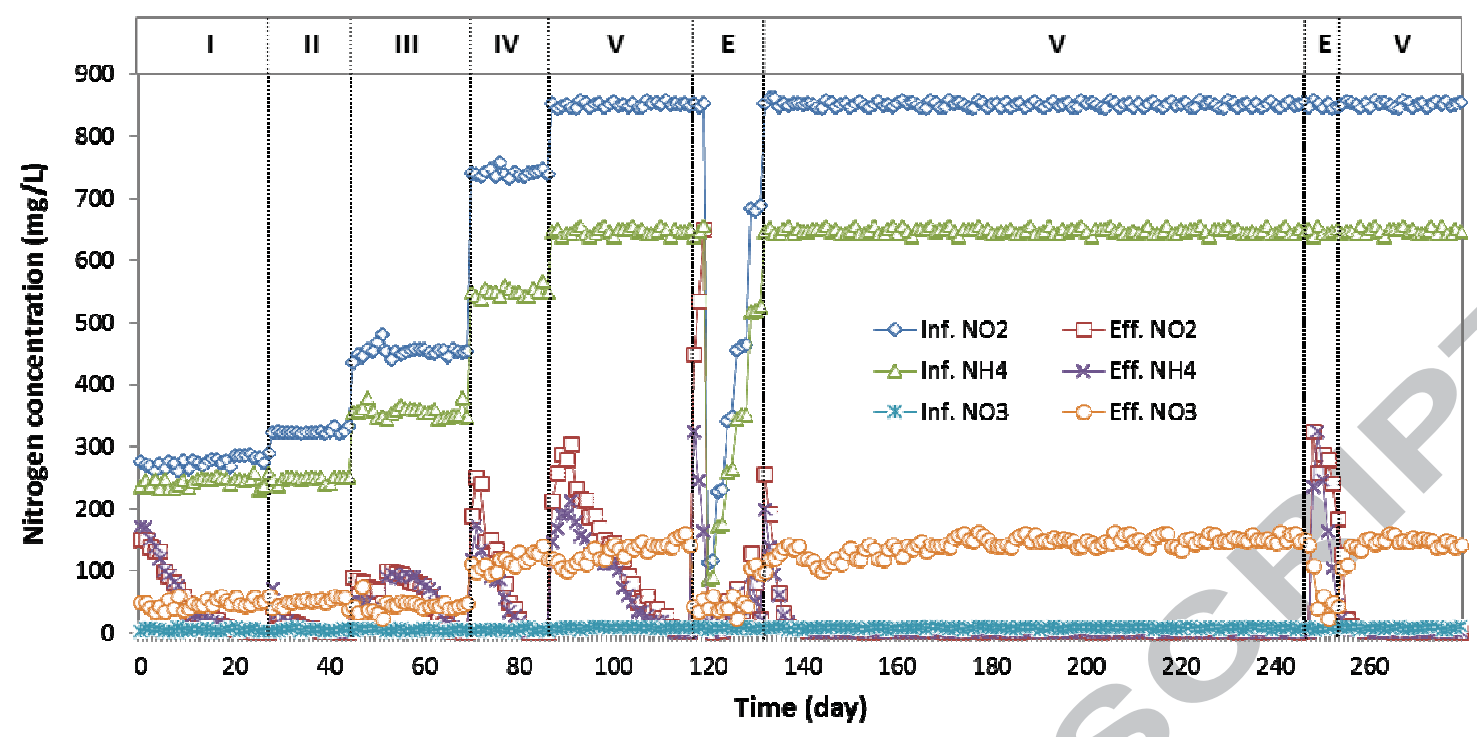

Figure 3. Time course of concentration of nitrogen species in the experiment 


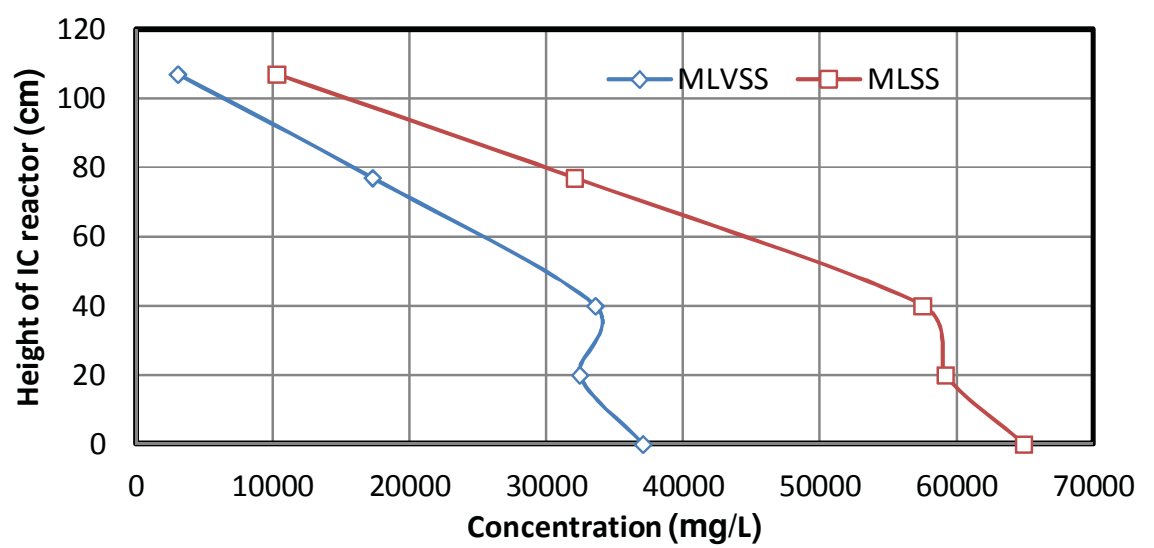

Figure 4. ANAMMOX sludge profile on day 280 


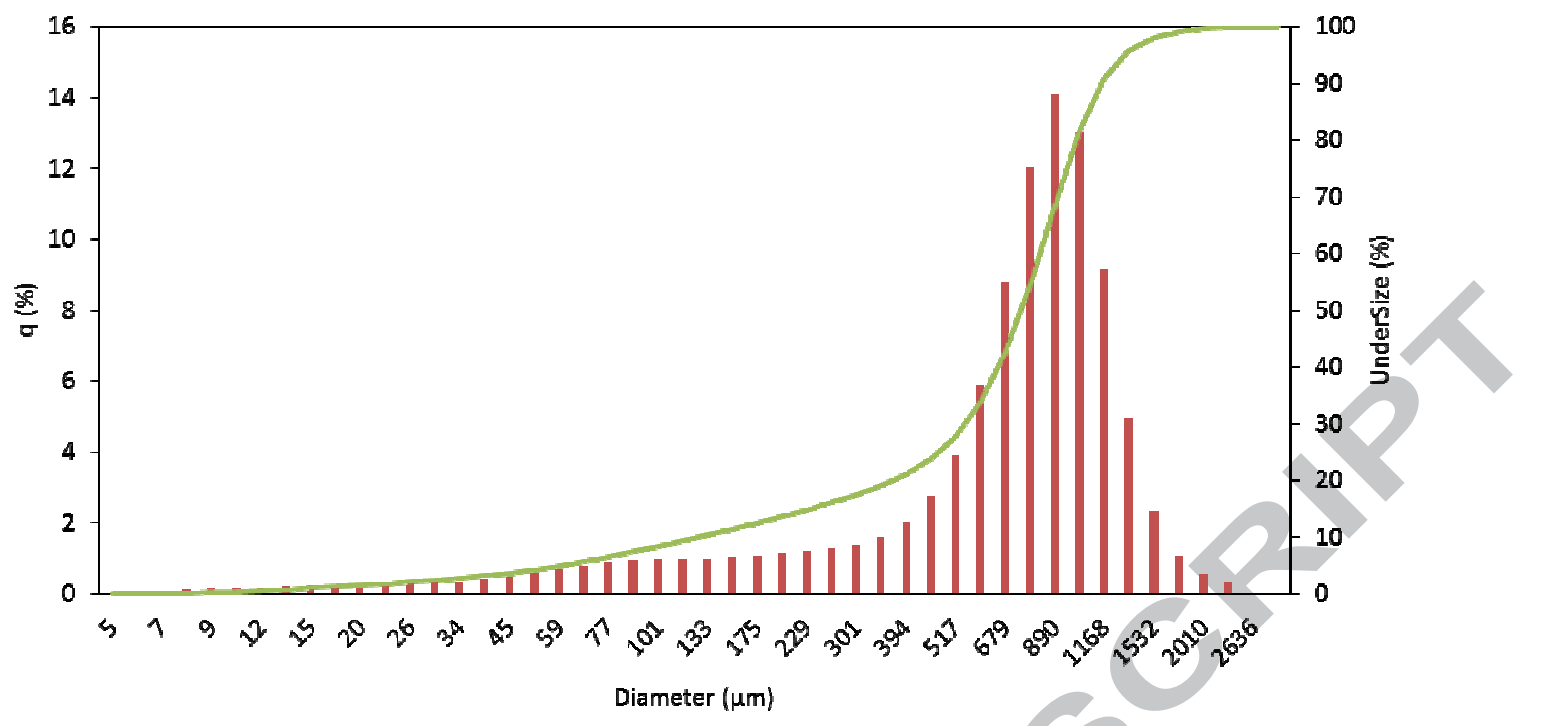

Figure 5. Granule size distribution of ANAMMOX sludge in IC reactor 
Table 1. Operating conditions of IC reactor

\begin{tabular}{|c|c|c|c|c|c|}
\hline & Phase I & Phase II & Phase III & Phase IV & Phase V \\
\hline Influent $\mathrm{NH}_{4}^{+}-\mathrm{N}, \mathrm{mg} \mathrm{N} \mathrm{L}^{-1}$ & $231-257$ & $238-251$ & $344-379$ & $538-566$ & $638-655$ \\
\hline Influent $\mathrm{NO}_{2}^{-}-\mathrm{N}, \mathrm{mg} \mathrm{N} \mathrm{L}^{-1}$ & $261-290$ & $321-323$ & $435-481$ & $732-757$ & $845-858$ \\
\hline $\mathrm{TN}$ loading rate, $\mathrm{mg} \mathrm{N} \mathrm{L}^{-1}$ & $2.1 \pm 0.05$ & $4.0 \pm 0.04$ & $6.0 \pm 0.09$ & $8.0 \pm 0.6$ & $10.0 \pm 0.4$ \\
\hline Influent flow rate, 1 day $^{-1}$ & 40 & 70 & 74 & 62 & 67 \\
\hline Circulation rate, 1 day $^{-1}$ & 67 & 67 & 67 & 67 & 67 \\
\hline Up-flow velocity, $\mathrm{m} \mathrm{h}^{-1}$ & 0.57 & 0.73 & & 0.68 & 0.71 \\
\hline HRT, h & 6.00 & 3.42 & & 3.87 & 3.63 \\
\hline Operating time, $\mathrm{d}$ & $1-28$ & $29-45$ & $6-70$ & $71-87$ & $88-280$ \\
\hline
\end{tabular}


Table 2. Result of SAA batch assays compared to other studies

\begin{tabular}{|c|c|c|c|}
\hline $\begin{array}{c}\text { SAA } \\
\left(\mathrm{g} \mathrm{N}_{2}-\mathrm{N} \mathrm{gVSS}^{-1} \mathrm{~d}^{-1}\right)\end{array}$ & References & ANAMMOX reactor & $\begin{array}{l}\text { Nitrogen concentration } \\
\left(\mathrm{mg} \mathrm{N} \mathrm{L}^{-1}\right)\end{array}$ \\
\hline $0.598 \pm 0.026$ & This study & IC with landfill leachate & $\mathrm{NH}_{4}-\mathrm{N}=\mathrm{NO}_{2}-\mathrm{N}=70$ \\
\hline $0.43 \pm 0.11$ & Scaglione et al., 2012 & $\begin{array}{l}\text { SBR with synthetic } \\
\text { wastewater }\end{array}$ & $\mathrm{NH}_{4}-\mathrm{N}$ \\
\hline $0.32 \pm 0.13$ & Scaglione et al., 2012 & SBR with landfill leachate & $\mathrm{NH}_{4}-\mathrm{N}=\mathrm{NO}_{2}-\mathrm{N}=70$ \\
\hline $0.28 \pm 0.02$ & $\begin{array}{l}\text { Dapena-Mora et al., } \\
2007\end{array}$ & $\begin{array}{l}\text { SBR with synthetic } \\
\text { wastewater }\end{array}$ & $\mathrm{NO}_{2}-\mathrm{N}$ \\
\hline $0.384 \pm 0.125$ & Lotti et al., 2012 & $\begin{array}{l}\text { IC tull-scale with digested } \\
\text { sludge wastewater }\end{array}$ & $\mathrm{NH}_{4}-\mathrm{N}=\mathrm{NO}_{2}-\mathrm{N}=50$ \\
\hline $0.54 \pm 0.10$ & Ruscalleda, 2011 & SBR with landfill leachate & $\mathrm{NH}_{4}-\mathrm{N}=\mathrm{NO}_{2}-\mathrm{N}=70$ \\
\hline
\end{tabular}


Table 3. Characteristics of ANAMMOX sludge in the study

\begin{tabular}{|c|c|c|c|c|}
\hline Diameter $(\mathrm{mm})$ & $0.5-1$ & $1-2$ & $2-3$ & $>3$ \\
\hline Settling velocity $\left(\mathrm{cm} \mathrm{s}^{-1}\right)$ & $2.03 \pm 0.12$ & $3.9 \pm 0.61$ & $7.96 \pm 0.67$ & $9.86 \pm 0.81$ \\
\hline Granule density $\left(\mathrm{g} \mathrm{cm}^{-3}\right)$ & $1.05-1.06$ & $1.06-1.07$ & $1.08-1.09$ & $1.09-1.10$ \\
\hline Calcium $\left(\mathrm{mgCa} \mathrm{gVSS}^{-1}\right)$ & $180 \pm 3.97$ & $211 \pm 2.83$ & $277 \pm 8.30$ & $373 \pm 1.48$ \\
\hline Magnesium $\left(\mathrm{mgMg} \mathrm{gVSS}^{-1}\right)$ & $9.50 \pm 1.81$ & $24.50 \pm 1.70$ & 41.00 & $58.90 \pm 0.89$ \\
\hline Iron $\left(\mathrm{mgFe} \mathrm{gVSS}^{-1}\right)$ & $11.71 \pm 0.62$ & $7.12 \pm 0.58$ & $4.28 \pm 0.46$ & $3.82 \pm 0.11$ \\
\hline Phosphorus (mgP gVSS ${ }^{-1}$ ) & $155 \pm 0.70$ & $164 \pm 0.25$ & $157 \pm 0.27$ & $163 \pm 0.34$ \\
\hline Granule distribution by particles (\%) & $57.59 \pm 3.86$ & & $2.23 \pm 0.92$ & $0.84 \pm 0.16$ \\
\hline Granule distribution by mass (\%) & 35.18 & & 22.57 & 25.94 \\
\hline VSS:SS ratio & 0.63 & 0.61 & 0.61 & 0.51 \\
\hline
\end{tabular}


Table 4. Dominant microbial members of granular sludge from IC reactor

\begin{tabular}{|c|c|c|c|c|c|c|}
\hline OTU\# & Taxonomy & $\begin{array}{c}\text { \# of } \\
\text { sequence }\end{array}$ & $\begin{array}{l}\text { RA } \\
(\%)\end{array}$ & Accession & similarity & References \\
\hline 1 & $\begin{array}{l}\text { Candidatus } \\
\text { Kueneniastuttgartiensis }\end{array}$ & 13261 & 37.45 & AF375995 & $98 \%$ & Schmid et al., 2001 \\
\hline 2 & $\begin{array}{l}\text { Uncultured bacterium (Found } \\
\text { from Anammox reactor) }\end{array}$ & 3125 & 8.83 & EF584533 & $98 \%$ & Bae et al., 2010 \\
\hline 3 & Uncultured bacterium & 1587 & 4.48 & KP372914 & $97 \%$ & Sun et al., 2015 \\
\hline 4 & $\begin{array}{l}\text { Uncultured planctomycete clone } \\
\text { 5GA_Pla_HKP_17 }\end{array}$ & 2800 & 7.91 & GQ356164 & & Park et al., 2010 \\
\hline 5 & $\begin{array}{l}\text { Uncultured Bacteroidetes } \\
\text { bacterium }\end{array}$ & 1900 & 5.37 & EF074300 & $90 \%$ & Unpublished \\
\hline 6 & $\begin{array}{l}\text { Uncultured Desulfuromonadales } \\
\text { bacterium }\end{array}$ & 1583 & 4.47 & KJ611805 & $98 \%$ & Pajares et al., 2015 \\
\hline
\end{tabular}




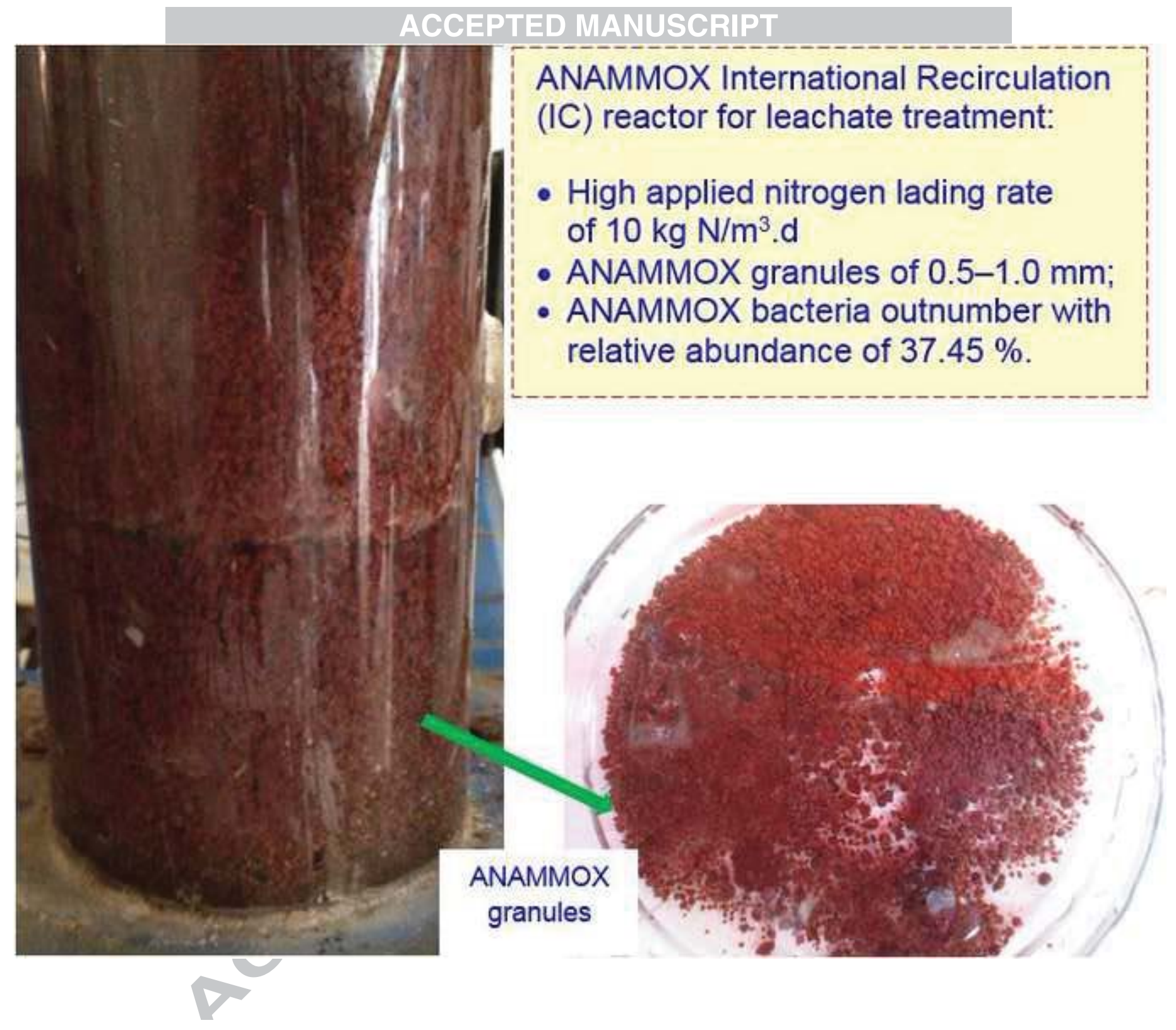




\section{Highlights}

- An Internal Circulation (IC) ANAMMOX reactor was used for leachate treatment

- The IC reactor achieved high nitrogen removal rate of $9.52 \mathrm{~kg} \mathrm{~N} \mathrm{~m}^{-3} \mathrm{~d}^{-1}$

- The specific ANAMMOX activity was found to be $0.598 \mathrm{gN}_{2}-\mathrm{N} \mathrm{gVSS}^{-1} \mathrm{~d}^{-1}$

- ANAMMOX granule size of $0.5-1.0 \mathrm{~mm}$ was the dominant in the $1 \mathrm{C}$ reactor

- Candidatus Kueneniastuttgartiensis was the major species (37.45\%) 